\title{
SPECIFICITY OF EMPLOYEES' CAREER ORIENTATIONS AND CREATIVITY IN A MODERN COMPANY
}

\author{
Anna Litvinova \\ Moscow City University of Psychology and Education (MCUPE), Moscow, Russia \\ E-mail: annaviktorovna@mail.ru \\ Sergey Chursin \\ Moscow Humanitarian-Technological Academy (MGTA), Moscow, Russia \\ E-mail: schursin21@mail.ru
}

\begin{abstract}
The study examines a career notion from the point of view of a personality development in professional activity. Particular attention is paid to career orientations as stable personality formations defining on one hand methods of control, stabilization and integration of an individual's career, and on the other hand, the way to professional self-development and personal growth. Correlations are analyzed between career orientations and motivation, and creativity of employees of an architectural design company $(N=21)$, realizing creative and regulated activity. Necessity to apply tests in order to identify career orientations, a person's motivation to achieve success, avoid failure, the personal, verbal and non-verbal creativity of the personality is reasoned in the empirical study. Obtained data state importance of creativity for the realization of a personal career depending on a type of professional activity. The results obtained during the research became a basis for the elaboration and implementation of programs for the development of a career and creative potential of the employees.
\end{abstract}

Key words: avoid failure, career orientations, creative activity, creative personality, creativity, verbal and non-verbal creativity.

\section{Introduction}

\section{Problem of the Research}

The purpose of Psychology in the present dynamic life is to explore the aspects of the human mental and behavioral activity at a company in order to ensure new approaches to finding a solution to existing, personal and organizational problems. One of them is a problem of creating a favorable environment for an individual development of company's employees and their career promotion. Researchers note that an individual's ability to realize his successful professional functions is more important to a company than the uniqueness and special qualities of his personality.

Therefore, it becomes important for psychology to study personal bases of career orientations and creative manifestations of professionals. It is accepted in human resources management to divide types of professional activities (Serbinovsky, 2007) into the regulated, where an executor does not 
54 bring to the work elements of novelty, and creative activity, aimed at creating new material wealth, technology, and spiritual values. This study includes activity of employees from project, marketing and Information Technology departments having creative character and more regulated activity of employees from legal and financial services. The research target is to reveal and substantiate correlation of career orientations with the staff motivation and creativity depending on a type of activity, realized by personnel.

\section{Focus of the Research}

There is no general interpretation of the term "career" in scientific literature. Experts consider a career as an employee's perception of success in his professional life and also the conscious behavior towards achieving professional goals. They also believe that a career is a process of an employee's production activity when, while being promoted, he masters new technologies, work techniques, methods, functional and professional duties. The experts consider a career as a sequence of job positions held by a person during his professional life.

In this study a career is identified as a conscious individual standpoint and behavior related to accumulation and use of growing human potential during a person's professional life. Career orientations are considered to be the ones that help an individual choose, define and model his professional and personal life.

From the point of view of E. Sheyn (Pochebut; Chiker, 2000) the career orientation is an important part of the professional "self-concept" that emerges in the process of socialization and helps control, stabilize and integrate one's career. The system of career orientations promotes meaningful ways for self-improvement and personal growth, and also includes both directions and ways of their implementation. L. G. Pochebut and V.A. Chiker who have translated and adapted "Career anchors" test of Edgar Shein, offer the following definitions of career orientations: 1) personal qualities, reflecting the availability of perceived top-priority needs in a personality professional structure, 2) personal dispositions of higher level (according to Yadov) which are stable formation and determine a person's professional career (Pochebut; Chiker, 2000). In both cases career orientations are related to the need-motivational sphere or a system of dispositions. The career orientation is a certain sense that people want to implement in choosing and implementing their career, it is a combination and sequence of individual attitudes related to the experience and activity in the field of lifelong work.

In recent studies based on the concept E. Sheyn some general trends of the career orientations in modern Russia were identified, first of all - a hierarchy of career orientations with a predominance of "stability of work place" and lower ranks of "professional competence" and "stability of residence place ". Career orientations can be changed to a large extent, they are socially stipulated and associated with the specificity of family education, age, professional orientation, a type of organizational culture of the company, country and city of residence and personal characteristics (Pochebut; Chiker, 2000). However, the specificity of relationship of career orientations with motivation to achieve success and manifestations of creativity in a specific professional activity was not studied.

Motivation is a process of creating a system of conditions or motives affecting a person's behavior, and directing his activity, as well as regulating intensity and stimulating the display of consciousness, assertiveness and diligence in achieving the company's goals.

The motive for success is defined as a generalized, relatively consistent disposition of personality, as well as a person's willingness to fulfil a task at a high level of performance in situations which present an opportunity to demonstrate his personal skills and abilities.

The second aspect of motivation is the motive to avoid failure and is considered to be an attempt to avoid mistakes. Researchers have different opinions on the correlation between the willingness to succeed and the avoidance of failure, and believe that they both are self- exclusive poles on a scale of values for the motive towards success. If a person is focused on success, he has no fear of failure and vice-versa. They also argue that a strong will for success may be combined with an equally strong fear of failure, especially if it leads to severe consequences. (Iljin, 2003).

It is proved by the empirical studies that creative persons are spontaneously active and removal of regulation leads to appearance of their abilities, the external motivation has no effect to manifest 
their creativity, low-creative persons are significantly affected by external stimulation of creativity

through an instruction (Druzhinin, 1997).

Nowadays, at this stage of development, the society needs a creative professional who is capable of adjusting to a rapid flow of information in the field of science and technology as well as capable of thinking creatively, developing and defending his point of view.

In the dictionary of Psychology, creativity is viewed as a level of an individual's creative talents and abilities which are relatively consistent traits of his personality

E. P. Torrance (as cited in Mesheryakov, Zinchenko, 2004) states that creativity includes hypersensitivity to problems, to insufficiency or contradictions of knowledge and also to actions towards specifying problems and finding solutions based on the proposed hypotheses, verification and alteration of these hypotheses and formulation of the solution. V. N. Druzhinin believes (2007) that creativity is a quality which emerges only under certain environmental circumstances. The conditions which are necessary for creativity to be revealed include the following: the absence of patterns of a regulated behavior, exposure to a positive model of creative behavior, a certain environment for imitation and social reinforcement of creative behavior.

C. Rogers was sure that the modern society does not cooperate with generating and developing of a creative personality. On the contrary, it levels down all the aspects of human life. He reasoned that after graduating from school, people tend to develop stereotyped thinking instead of being openminded with creative and original thinking (Rogers, 1994).

Nowadays, there is a growing interest in exploring the topic of creativity in a professional functioning of modern companies.

A correlation is revealed between the creativity level and with the motivation to achieve success and failure, (Chichuk, 2006), a comparative analysis of creativity and achievement motivation among students of the Faculty of Architecture and Design is made, as well as among working designers (Shelkova, 2006), creativity and career orientation are considered as professionally important qualities of professional advertising managers (Burmakova, 2005).

In our study creativity is considered to be a personality quality which promotes flexible thinking, implementation of a creative approach to reality as well as a successful career growth.

\section{Methodology of Research}

\section{General Background of the Research}

It is suggested that specific correlations exist between career orientations and motivation to achieve success, the avoidance of failure, and creativity (personal, verbal and non-verbal) at the company employees realizing creative and regulated activity depending on the gender and age of their personnel.

\section{Sample of the Research}

Employees of the architectural design company participated in this research. They were divided into two groups depending on their professional functions. The first group included employees with regulated activity ( $40 \%$ of the total sample group had an average age of 31.2 years and an equal number of men and women). The second group included employees with creative activity ( $60 \%$ of the total sample group had an average age of 30.8 years where men comprised $33.3 \%$, and women made up 66.7\%).

\section{Instruments and Procedures}

A set of below-mentioned tests was applied to substantiate the formulated assumption. The diagnostic methods of creativity of E. E. Tunic (2002) were applied to determine the characteristics of a creative personality: intellectual curiosity, imagination, complicity and risk tolerance. The diagnostic methods of non-verbal creativity of Torrance adapted by A. N. Voronin (Voronin, 1994) revealed general principles of the creativity assessment: the index of originality as a sum of original 
responses, divided by their total number, as well as the uniqueness index as a ratio of the number of unique responses divided by their total number. The diagnostic methods of the verbal creativity of S. Mednik adapted by A. N. Voronin (as cited in Istratova, 2006) reveals and assesses subjects' verbal creative potential which often remained hidden or blocked. Testing of the subjects' motivation to achieve success and avoid failure on T. Elers' scale (Raygorodsky, 1998) manifests the respective motivation. "Career Anchors" Test adapted by V. A. Chiker (Pochebut; Chiker, 2000) allows to determine a leading career orientation such as professional competence, management, autonomy/ independence as well as stability of work place and residence, service, challenge, integration of life styles and entrepreneurship.

\section{Data Analysis}

The correlation analysis by Pearson and Statistical program SPSS, version 17.0 have been applied to get the results of the empirical study.

\section{Results of the Research}

In order to explore correlations of creativity and career orientations depending on the type of employees' activity based on their gender and age, Pearson correlation analysis has been made. The obtained results are shown in Table. 1.

Table 1. Main correlations of creativity and career orientations of employees.

\begin{tabular}{|c|c|c|c|c|c|c|c|c|c|c|}
\hline \multirow[b]{2}{*}{ Parameters } & \multirow[b]{2}{*}{ Group } & \multirow[b]{2}{*}{ Gender } & \multirow[b]{2}{*}{ Age } & \multicolumn{2}{|c|}{ Personal creativity } & \multicolumn{2}{|l|}{ NVC } & \multicolumn{3}{|c|}{ Verbal creativity } \\
\hline & & & & 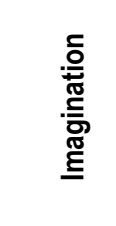 & 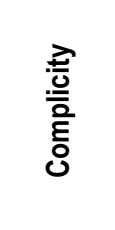 & 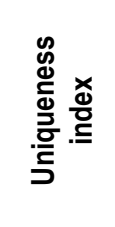 & 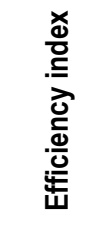 & 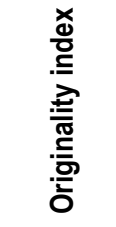 & 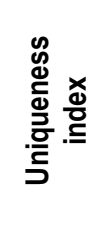 & 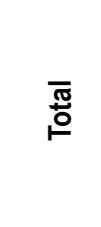 \\
\hline \multirow{2}{*}{ Gender } & 1 & & & $-0.87^{* \star}$ & $-0.71^{* *}$ & $-0.90^{* *}$ & & & & \\
\hline & 2 & & & $-0.60^{*}$ & $-0.81^{* *}$ & & $0.94^{* *}$ & $-0.92^{* *}$ & $-0.61^{*}$ & $-0.92^{* *}$ \\
\hline \multirow{2}{*}{ Age } & 1 & & & $-0.88^{* \star}$ & & $-0.89^{* *}$ & $-0.92^{\star *}$ & & & \\
\hline & 2 & & & & & & & & $0.79^{* \star}$ & \\
\hline \multirow{2}{*}{$\begin{array}{l}\text { Autonomy } \\
\text { (independence) }\end{array}$} & 1 & $-0.68^{\star}$ & & & & & & & & \\
\hline & 2 & & $0.79^{* *}$ & & & & & & $0.68^{*}$ & \\
\hline \multirow{2}{*}{$\begin{array}{l}\text { Stability of work } \\
\text { place }\end{array}$} & 1 & & & $-0.67^{*}$ & $-0.88^{\star *}$ & & & & $0.97^{* *}$ & \\
\hline & 2 & & $-0.85^{* *}$ & $0.81^{* *}$ & $0.68^{*}$ & & & & & \\
\hline \multirow{2}{*}{ Service } & 1 & & $0.71^{* *}$ & & & & $-0.77^{\star *}$ & & & \\
\hline & 2 & & & & & & $-0.66^{*}$ & $0.71^{* *}$ & $0.82^{* *}$ & $0.71^{* *}$ \\
\hline $\begin{array}{l}\text { Integration of life } \\
\text { styles }\end{array}$ & 2 & & & & & & $0.61^{*}$ & $-0.61^{*}$ & & $-0.61^{*}$ \\
\hline \multirow{2}{*}{ Business active } & 1 & & & & $-0.73^{\star *}$ & & & $-0.87^{\star *}$ & $0.89^{* *}$ & $-0.87^{* \star}$ \\
\hline & 2 & & & & & $0.97^{\star *}$ & & & $0.61^{*}$ & \\
\hline
\end{tabular}

*- Correlation is significant at level $0.05 ;{ }^{* *}$ - Correlation is significant at level 0.01

NVC - non-verbal creativity

It's necessary to note that no statistically significant correlations with motivation to achieve success and avoid failure have been revealed. Apparently, they are expressed equally at the company's 
employees, and other types of motivation contribute to the realization of their professional activities

The men in Group 1 had more apparent imagination and complicity of personal creativity as well as higher non-verbal uniqueness and career orientation "autonomy" than the women in the same group. The men also revealed much higher will for independence and freedom from instructions and restrictions. Imagination, non-verbal uniqueness and verbal efficiency were more common among younger people in Group 1 while more mature employees displayed a "service" type of career orientation with the goal to help others. Reconstructive imagination, low complexity and verbal uniqueness very closely correlated with "stability of work place" type of career orientation which promoted the staff's actions towards implementing the safety needs, events predictability, shifting responsibility for career management onto the administration. The negative correlation of "service" career orientation with verbal efficiency may indicate that the employees were somewhat conservative in their interactions with colleagues and partners. "Business active" career orientation negatively correlated with the complexity, originality, general creativity, but it correlated positively with verbal uniqueness. It is evident that there were more negative correlations than positive ones in Group 1. Apparently, other factors affected the formation of career orientations. However, it is necessary to note that verbal uniqueness made a positive contribution to career orientations of "stability of workplace" and "business active" types.

It was clear from the analysis that imagination and personal creativity complexity significantly prevailed in men of both Group 2 and Group 1, while differences were traced in originality, uniqueness and general verbal creativity. Verbal efficiency is more common among women from this group.

The younger employees of Group 2 were characterized by "stability of workplace" necessary for them to organize their life. The more mature workers valued a considerably high correlation with verbal uniqueness and career-orientation "autonomy" which was manifested in their willingness to decline a career promotion in order to preserve their independence.

"Stability of work place" index, in contrast with Group 1, positively correlated with more mature imagination and high complexity, and was a condition for the development of personal creativity.

"Service" career orientation as a "service to humanity" and a willingness to make the world a better place positively correlated with originality, uniqueness and general verbal creativity while demonstrating a negative correlation with verbal efficiency.

"Integration of life styles", on the contrary, correlated positively with verbal efficiency promoting harmonious life styles of the employees, and correlated negatively with originality and general verbal creativity with dominance in the sphere of professional life.

"Business active" correlated considerably with non-verbal and verbal uniqueness, which allowed them to overcome conscious and unconscious obstacles and risks associated with project performance and the development of marketing and promotional materials.

\section{Discussion}

It was revealed on the basis of obtained results that the largest number of correlations of creativity is more common to the company employees having career orientations of the «business active», «stability of work place» and «service». These data correlates with the general trend that the career orientation «stability of workplace» has more priority and «professional competence» and «stability of residence place» are less significant (Pochebut; Chiker, 2000). «Autonomy» is more common to men performing the regulated activity and to elder employees, engaged in creative activities. It corresponds to data revealing that future designers will exhibit the highest rates in the career orientation «autonomy», they aim to free themselves from institutional rules, to choose their own working speed and conditions, which conforms to specifics of «creative» professions (Burmakova, 2005). This study states that employees dealing with creative work, are distinguished with presence of the career orientation «integration of lifestyles,» revealing their desire for successful implementation in not only professional area but also in other spheres of life.

The interest of researchers to motivating reasons of realization of the individual's career is stipulated with conflicting data about manifestations of motivation to achieve success. The study observes no relation of the career orientations with motivation to achieve success and failure. It is 
possible that this fact is related to the fact that employees engaged in creative activities, are more focused on "service" rather than to achieve personal success, which is more typical for a mature personality. However, other studies have obtained different results. It is revealed that the designers have a significant decrease of motivation to avoid possible penalties and trouble, they are more confident and feel as highly qualified professional capable of performing any task (Shelkovoy, 2006). The personality with high social creativity differs by optimal motivation to achieve success, providing the potentially greater success. Moderately high motivation to achieve success, combined with a weak motive to avoid failure (high motivation to achieve success), increases productivity in goals realization and in reaching high and effective results (Chichuk, 2006).

The results obtained in the study demonstrate that creativity is making a significant contribution to the individual's career, depending on the type of professional activity. Only one positive correlation of unique verbal creativity with the career-orientation "business active" was revealed at employees who perform regulated activities. In contrast, the staff involved in the creative activity has $75 \%$ of correlations, positively related to various forms of creativity. These results correlate with to the fact that the highly creative personality differs from the low-creative one by conscious preference for areas of activity (becoming broad-minding person, improving education, developing knowledge), and low creativity involves the personality concentration on professional activity, the increased involvement in a production process, on conformance to norms and requirements of a profession (Chichuk, 2006). The creative trend is significantly increased at working designers having wider access to innovations in the "design world" and designers are constantly in the creative process, implementing new and relevant ideas when dealing with experts, (Shelkovoy, 2006).

\section{Conclusion}

The main idea of this study about the significance of creative potential for successful realization of an individual's career was confirmed in the empirical study: significant correlations between career orientations and verbal, non-verbal, and personal creativity, depending on the type of activity, were revealed. The obtained results revealed that each group had its own specific career orientations, expressions of creativity and correlations between them. The employees who performed regulated activity displayed mainly negative correlations with personal and verbal creativity; perhaps, excessive creativity could interfere with their professional duties. The largest number of correlations in this group was revealed between career orientations "stability of workplace", "business activities" and low complicity of personal creativity. Positive correlation was revealed between "business activities" and verbal uniqueness, necessary to establish positive communication and interaction with colleagues and partners.

The employees with creative activity demonstrated considerably high positive correlations of career orientations and creativity.

"Service" and "integration of life styles" most closely correlated with verbal originality, uniqueness, efficiency and general verbal creativity, "business activities" is highly correlated with non-verbal uniqueness that determined the effectiveness of their professional activities.

The obtained data can be used in elaboration and realization of programs of consultation and correction of problems of career management and development of employees' creative potential.

The data obtained in the research can be used in selection and assessment of personnel as well as career planning of employees in order to benefit company's human resources.

Further research of this subject is possible in the direction of study of personality and motivational factors, analysis of subjective characteristics and professional competencies in implementation of individual career targets.

\section{References}

Бурмакова, Ю. А. (2005). Профессионально важные качества в рекламной деятельности. Прикладная психология как ресурс социально-экономического развития современной России (Maтериальl межрегиональной научно-практической конференции. Факультет психологии МГУ им. М.В. Ломоносова, 17-20 ноября 2005 года). Москва: АНО УМО «Инсайт», с. 73-74. 
Воронин, А. Н. (1994). Методы психологической диагностики. Москва: DОСКнига.

Дружинин, В. Н. (2007). Проблемы общчих способностей (интеллект, обучаемость, креативность). Санкт-Петербург: Питер.

Дружинин, В. Н. (1997). Диагностика общих познавательных способностей. Когнитивное обучение: современное состояние и перспективы. Москва: ИП РАН, с. 60-69.

Ильин, Е. П. (2003) Мотивация и мотивы. Санкт-Петербург: Питер.

Истратова, О. Н. (2006). Психодиагностика. Ростов н/Д: Феникс.

Мещеряков, Б., Зинченко, В. (2004). Большой психологический словарь. Москва: Олма-пресс.

Почебут, Л. Г., Чикер, В. А. (2000). Организационная социальная психология. Санкт-Петербург: Речь.

Райгородский, Д. Я. (1998). Практическая психодиагностика. Методики и тесты. Учебное пособие. Самара: Бахрах.

Роджерс, К. (1994). Взгляд на психотерапию. Становление человека. Москва: Прогресс.

Сербиновский, Б. Ю. (2007). Управление персоналом. Москва: ИТК «Дашков и К».

Туник, Е. Е. (2002). Психодиагностика творческого мышиения. Креативные тесты. Москва: Дидактика Плюс.

Чичук, Е. Ю. (2006). Социальная креативность как компонент самоактуализации личности в социономической деятельности. Человек. Сообщество. Управление: науч.-инф. журн. Спец. вып. № 1.Краснодар: КубГУ.

Шелковой, Ю. С. (2006). Изучение структуры профессионального самосознания дизайнера. Человек. Сообщество. Управление. Взгляд молодого исследователя: Матер. науч.-практич. конф. Краснодар. Ч. 2. С. 92-94.

Advised by Guna Svence, Riga Teacher Training and Educational Management Academy, Latvia

Received: April 22, 2012

Accepted: July 09, 2012

Anna Litvinova

PhD, Associate Professor, Moscow City University of Psychology and Education (MCUPE), Moscow, Russia.

E-mail: annaviktorovna@mail.ru

Sergey Chursin Student, Moscow Humanitarian-Technological Academy (MGTA), Moscow, Russia

E-mail: schursin21@mail.ru 